\title{
Optimasi dan Validasi Metode Penentuan Kadar Asam Glikolat dan Asam Laktat Dalam Krim Menggunakan Kromatografi Cair Kinerja Tinggi
}

\author{
Devi Wulandari ${ }^{a}$, Gusrizal Gusrizal $^{a *}$, Titin Anita Zaharah ${ }^{a}$ \\ ${ }^{a}$ Jurusan Kimia, Fakultas Matematika dan Ilmu Pengetahuan Alam, Universitas Tanjungpura, \\ Jl. Prof. Dr. H. Hadari Nawawi, Pontianak 78124 \\ *Corresponding author \\ E-mail : gusrizal@chemistry.untan.ac.id
}

DOI: 10.20961/alchemy.16.1.34008.10-24

Received 19 August 2019, Accepted 07 February 2020, Published 01 March 2020

\begin{abstract}
ABSTRAK
Telah dilakukan optimasi dan validasi metode penentuan asam glikolat dan asam laktat dalam krim menggunakan kromatografi cair kinerja tinggi. Pemisahan asam glikolat dan asam laktat dilakukan pada kolom fasa balik C-8 menggunakan fasa gerak asam ortofosfat $0,1 \%$ dengan $\mathrm{pH} 3,5$ dan detektor $U V$-Visible. Standar asam glikolat dan asam laktat dibuat dengan melarutkannya menggunakan asam ortofosfat $0,1 \% \mathrm{pH}$ 3,5. Hasil eksperimen menunjukkan bahwa pada rentang konsentrasi $25-400 \mu \mathrm{g} / \mathrm{mL}$, asam glikolat dan asam laktat memiliki kurva yang linear dengan koefisien korelasi masing-masing 0,9997 dan 0,9999. Uji presisi untuk larutan standar berkonsentrasi $100 \mu \mathrm{g} / \mathrm{mL}$ menghasilkan simpangan baku relatif sebesar 1,49\% untuk asam glikolat dan $1,72 \%$ untuk asam laktat. Metode yang telah dioptimasi memberikan akurasi yang baik yang ditunjukkan oleh nilai perolehan kembali dari pengukuran tiga spiked sample dengan konsentrasi berbeda $(50,100$, dan $150 \mu \mathrm{g} / \mathrm{mL})$. Nilai perolehan kembali untuk masing-masing konsentrasi spiked sample adalah $97,12 \% \pm 0,69 ; 98,76 \% \pm 0,43 ; 100,80 \% \pm 0,29$ untuk asam glikolat dan 97,58\% $\pm 0,39 ; 96,20 \% \pm$ 0,$68 ; 98,00 \% \pm 0,38$ untuk asam laktat. Batas deteksi dan batas kuantisasi untuk asam glikolat adalah 0,05 dan $0,17 \mu \mathrm{g} / \mathrm{mL}$, sedangkan untuk asam laktat adalah 1,40 dan 4,67 $\mu \mathrm{g} / \mathrm{mL}$. Nilai kekasaran metode untuk asam glikolat pada hari pertama dan hari kedua adalah 1,43\% dan 1,67\%, sedangkan untuk asam laktat adalah $1,67 \%$ dan $1,25 \%$. Metode yang telah dioptimasi dan divalidasi berpotensi untuk digunakan secara spesifik pada penentuan kadar asam glikolat dan asam laktat dalam krim.
\end{abstract}

Kata kunci: asam glikolat, asam laktat, kromatografi, optimasi, validasi

\begin{abstract}
Optimization and Validation of Determination Methods of Glycolic Acid and Lactic Acid in Cream Using High-Performance Liquid Chromatography. A high-performance liquid chromatography analytical method for the determination of glycolic acid and lactic acid in creams has been optimized and validated. The separation was performed in a reverse phase $\mathrm{C}-8$ column with a mobile phase of $0.1 \%$, orthophosphoric acid at pH 3.5, and UV-Visible detector. The standard of glycolic acid and lactic acid was dissolved in $0.1 \%$ orthophosphoric acid at $\mathrm{pH} 3.5$. The experimental results showed that in the concentration range of $25-400 \mu \mathrm{g} / \mathrm{mL}$, glycolic acid and lactic acid showed a linear curve with a correlation coefficient of 0.9997 and 0.9999 , respectively. The precision test for standard solutions containing $100 \mu \mathrm{g} / \mathrm{mL}$ resulted in a relative standard deviation of $1.49 \%$ for glycolic acid and $1.72 \%$ for lactic acid. The optimized method provided good accuracy indicated by the recovery of the measurement of three spiked samples in different
\end{abstract}


concentrations $(50,100$, and $150 \mu \mathrm{g} / \mathrm{mL})$. The recovery for each concentration of the spiked sample was $97.12 \% \pm 0.69 ; 98.76 \% \pm 0.43 ; 100.80 \% \pm 0.29$ for glycolic acid and $97.58 \% \pm 0.39 ; 96.20 \% \pm 0.68 ; 98.00 \%$ \pm 0.38 for lactic acid. The limit of detection and limit of quantization for glycolic acid was 0.05 and 0.17 $\mu \mathrm{g} / \mathrm{mL}$, and for lactic acid was 1.40 and $4.67 \mu \mathrm{g} / \mathrm{mL}$. The ruggedness of the method for glycolic acid on the first day and second day was $1.43 \%$ and $1.67 \%$, while for lactic acid, it was $1.67 \%$ and $1.25 \%$. The method that has been optimized and validated shows the potential to be used specifically for the determination of glycolic acid and lactic acid in the cream.

Keywords: chromatography, glycolic acid, lactic acid, optimization, validation

\section{PENDAHULUAN}

Asam glikolat dan asam laktat merupakan salah satu senyawa golongan alpha hydroxy acids (AHAs) yang sering diformulasikan secara terpisah atau ditambahkan secara bersama dalam kosmetik. Asam glikolat dan asam laktat dapat memberikan efek berupa penampakan kulit yang lebih halus, mengurangi keriput, dan mengurangi bintik-bintik pada kulit (Burgess, 2005). Asam glikolat mempunyai rumus kimia $\mathrm{CH}_{2} \mathrm{OHCOOH}$ dengan nilai $\mathrm{pKa}=3,82$ dan larut dalam pelarut polar (Huang et al., 2002). Asam glikolat merupakan senyawa golongan AHAs yang mengandung gugus karboksil, sedangkan senyawa AHAs yang lain merupakan turunan dari asam glikolat. Asam glikolat banyak dijumpai pada tebu (Baran and Maibach, 2010). Asam laktat adalah senyawa golongan

AHAs dengan gugus metil yang terikat pada karbon alfa $(\alpha)$ asam glikolat. Asam laktat mempunyai rumus kimia $\mathrm{CH}_{3} \mathrm{CHOHCOOH}$ dengan nilai $\mathrm{pKa}=3,86$ dan dapat larut dalam pelarut polar (Huang et al., 2002). Asam laktat banyak dijumpai pada buah tomat (Baran and Maibach, 2010).

Asam glikolat dan asam laktat memiliki efek samping bila digunakan secara berlebihan atau digunakan pada sediaan dengan $\mathrm{pH}$ kurang dari 3,5. Efek samping tersebut berupa rasa pedih, rasa terbakar, dan iritasi (Burgess, 2005). Asam glikolat dan asam laktat efektif digunakan pada produk kosmetik dengan konsentrasi 1-5\%, dan konsentrasi tertinggi penggunaan dapat mencapai $15 \%$ bila digunakan dibawah pengawasan dokter atau ahli kecantikan (Butler, 2010).

Terkait dengan efek samping yang ditimbulkan, peredaran kosmetik yang mengandung asam glikolat dan asam laktat memerlukan pengawasan dari lembaga yang berwenang. Pengawasan diperlukan untuk menjamin keamanan konsumen atas produk kosmetik yang dipakai. Penggunaan asam glikolat dan asam laktat dalam kosmetik telah diatur oleh Peraturan Kepala Badan Pengawas Obat dan Makanan Republik Indonesia nomor 18 tahun 2015 dengan kadar maksimum 10\% dan $\mathrm{pH}$ sediaan 3,5 atau lebih. 
Meskipun telah diatur, pengawasan terhadap penggunaan asam glikolat dan asam laktat dalam sediaan kosmetik masih belum dilakukan karena belum tersedianya metode standar.

Berbagai penelitian telah dilakukan untuk menentukan kadar asam glikolat dan asam laktat dalam berbagai macam matriks. Penelitian tersebut menggunakan metode spekrofotometri, kromatografi cair kinerja tinggi (KCKT) maupun kromatografi gas (KG). Moldovan et al. (2017) melakukan penentuan asam glikolat dalam matriks produk pencerah kulit dengan metode spektrofotometri derivatif. Huang et al. (2002) melakukan penentuan kadar asam glikolat dan asam laktat dalam produk kosmetik menggunakan metode KCKT. Penentuan kadar asam glikolat dan asam laktat secara kromatografi gas pernah dilakukan oleh Molever (2002) menggunakan matriks berupa hand lotion dan krim.

Mubarak et al. (2013) melakukan pengembangan dan optimasi metode penentuan kadar asam glikolat dalam matriks krim dan snail mисиs secara KCKT. Pengembangan dan optimasi metode asam glikolat dan asam laktat juga dilakukan oleh Zamanova et al. (2014) dan Kishore et al. (2013) pada sampel dengan matriks berupa monomer penyusun polimer biodegradable. Penelitian yang sama juga dilakukan oleh Ahmed et al. (2014) yang memvalidasi metode penentuan asam laktat pada matriks berupa senyawa disinfektan.

Pada tulisan ini dijelaskan optimasi dan validasi metode penentuan asam glikolat dan asam laktat yang dilakukan terhadap sampel sediaan kosmetik dengan matriks berupa krim. Asam glikolat dan asam laktat dalam krim bercampur dengan zat-zat lain yang sebagian mempunyai sifat hampir sama. Zat-zat yang terkandung dalam krim antara lain: pengawet, pelembab, pencerah, parfum, pengemulsi, dan lain-lain.

Berbeda dengan penelitian yang telah ada sebelumnya dimana penentuan asam glikolat dan asam laktat secara KCKT menggunakan kolom non polar (C-18) (Huang et al., 2002; Zamanova et al., 2014; Kishore et al., 2013; Mubarak et al., 2013; Ahmed et al. 2014), pada tulisan ini dijelaskan optimasi dan validasi metode secara KCKT terhadap sampel krim yang mengandung asam glikolat dan asam laktat secara bersamaan menggunakan kolom semi polar (C-8). Melalui penurunan kepolaran kolom, diharapkan interaksi asam glikolat dan asam laktat yang merupakan senyawa polar dengan kolom menjadi lebih intensif sehingga berdampak terhadap resolusi pemisahan di dalam kolom. Parameter validasi yang diuji meliputi linieritas, presisi, akurasi, batas deteksi, batas kuantisasi, dan kekasaran.

\section{METODE PENELITIAN}

Bahan-bahan yang digunakan dalam optimasi dan validasi metode antara lain: 
aquademineralisata, amonia 25\% (Emsure $\left.{ }^{\circledR}\right)$, asam glikolat (Reagen Plus ${ }^{\circledR}$ 99\% SigmaAldrich), asam laktat 88,0-92,0\% (Sigma-Aldrich), asam ortofosfat 85\% (Emsure®), asetonitril (Lichrosolv®), dan n-hexan (Emsure $\left.{ }^{\circledR}\right)$.

Optimasi dan validasi metode menggunakan peralatan: KCKT Shimadzu LC-20AD yang terhubung dengan detektor $U V$-Vis SPD-20A dan detektor PDA SPD-M20A, kolom C-8 YMC-Triart 250x4,6 mml.D.S-5 $\mu$ m, sonikasi Branson 880, vortex mixer UM 300, neraca analitik Precisa XB 220A, neraca analitik Mettler Toledo AG 283, Ultrapure water directQ® 5UV-R, Millex samplicity® filters.

\section{Optimasi Metode}

Optimasi metode yang dilakukan meliputi optimasi pelarut, optimasi panjang gelombang detektor, dan optimasi fasa gerak. Optimasi terhadap pelarut dilakukan dengan cara membuat masing-masing larutan induk asam glikolat dan asam laktat dengan konsentrasi $1000 \mu \mathrm{g} / \mathrm{mL}$ menggunakan pelarut asam ortofosfat $0,1 \%$ pada berbagai $\mathrm{pH}$, yaitu 3,$5 ; 3,8$; dan 4,1 . Pengkondisian $\mathrm{pH}$ asam ortofosfat $0,1 \%$ dilakukan dengan cara penambahan larutan ammonia 25\%. Larutan standar asam glikolat dan asam laktat yang digunakan untuk optimasi metode berkonsentrasi $100 \mu \mathrm{g} / \mathrm{mL}$.

Optimasi panjang gelombang detektor dilakukan menggunakan larutan standar tunggal asam glikolat dan asam laktat dalam pelarut asam ortofosfat $0,1 \% \mathrm{pH} \mathrm{3,5.} \mathrm{Larutan}$ standar asam glikolat dan asam laktat sebanyak $20 \mu \mathrm{L}$ diinjeksikan ke dalam alat KCKT yang terhubung dengan detektor PDA. Rentang panjang gelombang yang digunakan dalam pengukuran adalah $190-230 \mathrm{~nm}$.

Optimasi fasa gerak dilakukan dengan cara memvariasikan komposisi larutan asam

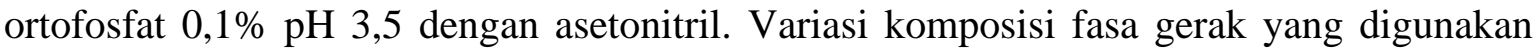

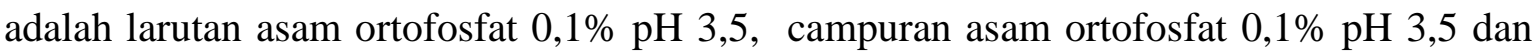
asetonitril dengan perbandingan komposisi volume (v/v) 90:10, 80:20, dan 70:30.

Larutan spiked sample dengan konsentrasi $100 \mu \mathrm{g} / \mathrm{mL}$ dibuat dengan cara melarutkan stok spiked sample konsentrasi $0,010 \mathrm{~g} / \mathrm{g}$. Larutan spiked sample dilarutkan dengan campuran asam ortofosfat $0,1 \% \mathrm{pH} 3,5$ dan asetonitril dengan perbandingan volume (v/v) 30:70. Larutan spiked sample disonikasi dan dipanaskan pada penangas air suhu $60{ }^{\circ} \mathrm{C}$ selama 15 menit kemudian dihomogenkan dengan menggunakan alat vortex. Larutan spiked sample diekstraksi dengan $30 \mathrm{~mL}$ n-heksan sebanyak 2 kali. Lapisan bawah diambil dan diencerkan dengan larutan asam ortofosfat $0,1 \% \mathrm{pH} \mathrm{3,5}$ hingga diperoleh 
konsentrasi $100 \mu \mathrm{g} / \mathrm{mL}$. Larutan spiked sample disaring dengan penyaring millipore 0,45 $\mu \mathrm{m}$.

\section{Analisis secara Kromatografi Cair Kinerja Tinggi}

Pelarut asam ortofosfat $0,1 \% \mathrm{pH} 3,5$, larutan standar tunggal asam glikolat dan asam laktat, larutan standar campuran asam glikolat dan asam laktat, dan spiked sample sebanyak $20 \mu \mathrm{L}$ diinjeksikan ke dalam alat KCKT dengan rentang panjang gelombang detektor 190-230 nm. Proses pemisahan terjadi di kolom fasa terbalik C-8 menggunakan fasa gerak larutan asam ortofosfat $0,1 \% \mathrm{pH} 3,5$ dan campuran larutan asam ortofosfat $0,1 \%$ $\mathrm{pH}$ 3,5 dan asetonitril dengan laju alir $1 \mathrm{~mL} / \mathrm{min}$.

\section{Validasi metode}

Validasi metode secara KCKT dilakukan dengan mengukur parameter berupa linearitas, presisi, akurasi, batas deteksi, batas kuantisasi, dan kekasaran (ruggedness). Validasi metode pada penelitian ini menggunakan alat KCKT dengan panjang gelombang

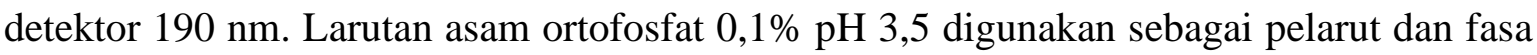
gerak. Linearitas ditentukan dengan mengukur lima konsentrasi larutan standar yaitu: 25, 50, 100, 200, dan $400 \mu \mathrm{g} / \mathrm{mL}$. Larutan standar diinjeksikan ke dalam alat KCKT dengan 3 kali pengulangan. Rata-rata luas area puncak diplotkan terhadap konsentrasi untuk menghitung linearitas.

Presisi ditentukan dengan cara menginjeksikan larutan standar konsentrasi 100 $\mu \mathrm{g} / \mathrm{mL}$ ke dalam alat KCKT sebanyak 10 kali. Dari data simpangan baku (SD) dan ratarata luas area yang diperoleh melalui 10 kali pengulangan injeksi (X) dapat dihitung simpangan baku relatif (RSD) dengan persamaan (1).

$$
\text { Simpangan baku relatif }(\% \mathrm{RSD})=\frac{\mathrm{SD}}{\mathrm{X}} \times 100 \%
$$

Penentuan akurasi dilakukan dengan cara membuat tiga konsentrasi larutan spiked sample yaitu: 50, 100, dan $150 \mu \mathrm{g} / \mathrm{mL}$. Masing-masing larutan spiked sample ini diinjeksikan ke dalam alat KCKT. Nilai akurasi dihitung dengan perhitungan \% recovery menggunakan persamaan (2).

$$
\text { Recovery }(\%)=\frac{\text { Kadar analit hasil validasi }}{\text { Kadar analit teoritis }} \times 100 \%
$$

Penetapan batas deteksi (limit of detection, LOD) dan batas kuantisasi (limit of quantitation, LOQ) dilakukan dengan menggunakan pendekatan signal noise (ICH, 2005). 
Noise merupakan gangguan yang berasal dari matriks sedangkan signal adalah respon analit yang ditunjukkan dengan adanya puncak-puncak yang muncul pada kromatogram. Batas deteksi dan batas kuantisasi berturut-turut dihitung menggunakan persamaan (3) dan (4).

$$
\begin{aligned}
& \text { LOD }=3 \times \frac{\text { signal }}{\text { noise }} \times \text { konsentrasi standar } \\
& \text { LOQ }=10 \times \frac{\text { signal }}{\text { noise }} \times \text { konsentrasi standar }
\end{aligned}
$$

Penentuan kekasaran dilakukan untuk mengetahui ketahanan fasa gerak dalam kurun waktu dua hari dengan menggunakan alat KCKT yang berbeda dengan yang digunakan untuk optimasi. Larutan standar asam glikolat dan asam laktat konsentrasi 100 $\mu \mathrm{g} / \mathrm{mL}$ diinjeksikan ke dalam alat KCKT sebanyak 6 kali pengulangan. Dari data simpangan baku (SD) dan rata-rata luas area yang diperoleh melalui 6 kali pengulangan injeksi (X) dapat dihitung simpangan baku relatif (RSD) dengan persamaan (5).

$$
\text { LOQ }=10 \times \frac{\text { signal }}{\text { noise }} \times \text { konsentrasi standar }
$$

\section{HASIL DAN PEMBAHASAN Optimasi Metode}

Optimasi metode dilakukan berdasarkan pada keberadaan asam glikolat dan asam laktat dalam sediaan krim yang mengandung bahan yang cukup kompleks. Krim yang digunakan adalah krim produk komersial. Pemisahan yang baik dengan tingkat resolusi yang tinggi pada kromatogram, hasil data dengan akurasi yang tinggi, dan analisis dengan waktu yang relatif cepat merupakan tujuan utama optimasi metode dilakukan.

Optimasi metode yang dilakukan dalam penelitian ini meliputi optimasi pelarut, optimasi panjang gelombang detektor, dan optimasi fasa gerak. Optimasi pelarut bertujuan untuk mendapatkan profil kromatogram yang simetris. Optimasi pelarut dilakukan dengan menggunakan asam ortofosfat $0,1 \%$ pada berbagai $\mathrm{pH}$, yaitu 3,5, 3,8, dan 4,1. Kromatogram yang diperoleh menunjukkan bahwa pelarut asam ortofosfat $0,1 \%$ dengan $\mathrm{pH}$ 3,5 memberikan hasil berupa resolusi, tailing factor, dan theoritical plate yang paling baik dibandingkan dengan menggunakan asam ortofosfat $0,1 \% \mathrm{pH} \quad 3,8$ dan 4,1 sebagaimana terlihat pada Tabel 1.

Pemilihan asam ortofosfat $0,1 \%$ sebagai pelarut dikarenakan asam ortofosfat $0,1 \%$ memberikan respon absorbansi paling kecil pada panjang gelombang sekitar $200 \mathrm{~nm}$ dibanding dengan pelarut asam atau pelarut buffer lain seperti: asam asetat $1 \%$, 
trifluoroasetik 0,1\%, amonium fosfat dibasa, amonium asetat, amonium bikarbonat (Snyder et al., 1997). Larutan asam ortofosfat $0,1 \% \mathrm{pH} 3,5$ mempunyai $\mathrm{pH}$ yang lebih rendah dari $\mathrm{pH}$ asam glikolat dan asam laktat sehingga mencegah terjadinya ionisasi gugus asam dari asam glikolat dan asam laktat.

Tabel 1. Hasil optimasi pelarut dari larutan standar tunggal asam glikolat dan asam laktat pada $\mathrm{pH} 3,5 ; 3,8$; dan 4,1 .

\begin{tabular}{|c|c|c|c|c|}
\hline \multirow{2}{*}{ Zat Aktif } & \multirow{2}{*}{ Parameter } & \multicolumn{3}{|c|}{ Pelarut Asam Ortofosfat $0,1 \%$} \\
\hline & & $\mathrm{pH} \mathrm{3,5}$ & $\mathrm{pH} 3,8$ & $\mathrm{pH} \mathrm{4,1}$ \\
\hline \multirow[t]{5}{*}{ Asam glikolat } & Waktu retensi (menit) & 3,448 & 3,238 & 3,291 \\
\hline & Area & 814473 & 1205093 & 443631 \\
\hline & Tailing factor & 1,099 & 0,000 & 0,935 \\
\hline & Resolusi & 2,251 & 0,878 & 1,166 \\
\hline & Theoritical plate & 5434,201 & 1384,725 & 3759,823 \\
\hline \multirow[t]{5}{*}{ Asam laktat } & Waktu retensi (menit) & 4,906 & 3,989 & 4,385 \\
\hline & Area & 507950 & 962451 & 221597 \\
\hline & Tailing factor & 1,072 & 0,000 & 0,872 \\
\hline & Resolusi & 6,313 & 0,000 & 0.281 \\
\hline & Theoritical plate & 7642,880 & 854,560 & 4976,689 \\
\hline
\end{tabular}

Optimasi panjang gelombang menggunakan detektor photodiode array (PDA) dilakukan pada rentang panjang gelombang $190-230 \mathrm{~nm}$. Hasil penelitian menunjukkan bahwa panjang gelombang $190 \mathrm{~nm}$ merupakan panjang gelombang maksimal sebagaimana terlihat pada Tabel 2. Panjang gelombang maksimal merupakan panjang gelombang dimana asam glikolat dan asam laktat mempunyai serapan paling tinggi yang dinyatakan dengan besarnya luas area. Asam glikolat dan asam laktat yang dideteksi pada panjang gelombang $190 \mathrm{~nm}$ mempunyai luas area paling besar bila dibanding dengan luas area pada panjang gelombang yang lain. Penggunaan panjang gelombang maksimal dalam analisis akan menghasilkan kepekaan maksimal, dan jika dilakukan pengukuran ulang maka kesalahan yang disebabkan oleh pemasangan ulang panjang gelombang akan kecil sekali (Gandjar and Rohman, 2008). 
Tabel 2. Luas area puncak larutan standar asam glikolat dan asam laktat yang diukur pada berbagai panjang gelombang

\begin{tabular}{ccc}
\hline Panjang Gelombang $(\mathrm{nm})$ & Luas Area Asam Glikolat & Luas Area Asam Laktat \\
\hline 190 & 814473 & 507950 \\
200 & 183680 & 94179 \\
210 & 86679 & 58177 \\
220 & 32517 & 29233 \\
230 & 9756 & 10751 \\
\hline
\end{tabular}

Optimasi fasa gerak bertujuan untuk mencari komposisi fasa gerak yang dapat memisahkan asam laktat dan asam glikolat dengan senyawa lain seperti pengawet dan pewarna. Variasi fasa gerak yang digunakan dalam penelitian meliputi: larutan asam

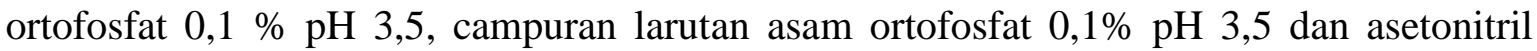
dengan perbandingan volume (v/v) 90:10, 80:20, dan 70:30. Fasa gerak yang menggunakan larutan asam ortofosfat $0,1 \% \mathrm{pH} \mathrm{3,5}$ memberikan hasil berupa resolusi yang paling baik dengan nilai resolusi yang lebih besar dari 1,5 dibanding menggunakan fasa gerak lain sebagaimana terlihat pada Gambar 1.

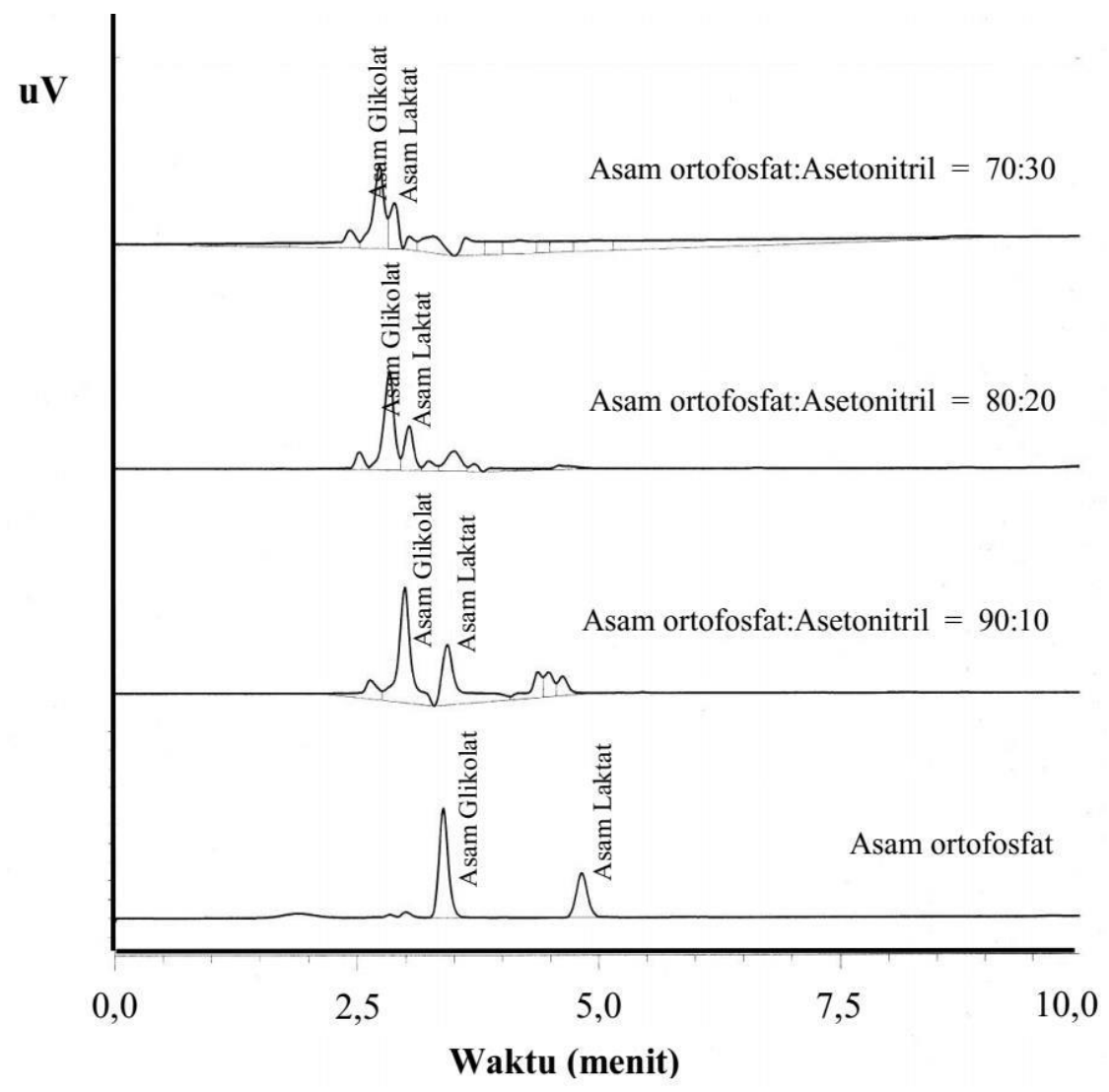

Gambar 1. Kromatogram larutan standar asam glikolat dan asam laktat $100 \mu \mathrm{g} / \mathrm{mL}$ yang dielusi dengan berbagai variasi komposisi fasa gerak. 
Asetonitril yang terdapat dalam larutan fasa gerak menyebabkan senyawa-senyawa yang bersifat polar dan nonpolar dalam larutan spiked sample memberikan respon di sekitar panjang gelombang $190 \mathrm{~nm}$. Senyawa-senyawa tersebut akan tertahan di dalam kolom lebih lama sehingga senyawa yang memiliki tingkat kepolaran hampir sama akan terjadi pemisahan yang saling tumpang tindih. Pemisahan senyawa yang tidak sempurna akan menghasilkan kromatogram dengan tingkat resolusi kurang dari 1,5. Penambahan asetonitril ke dalam asam ortofosfat menyebabkan perubahan kepolaran asam ortofosat sebagai fasa gerak. Perubahan kepolaran ini berpengaruh terhadap parameter pemisahan seperti faktor retensi dan kesimetrisan kromatogram (Raeni et al., 2018). Kromatogram yang diperoleh dari pengukuran campuran asam glikolat dan asam laktat serta spiked sample menggunakan metode yang telah dioptimasi dapat dilihat pada Gambar 2 dan 3.

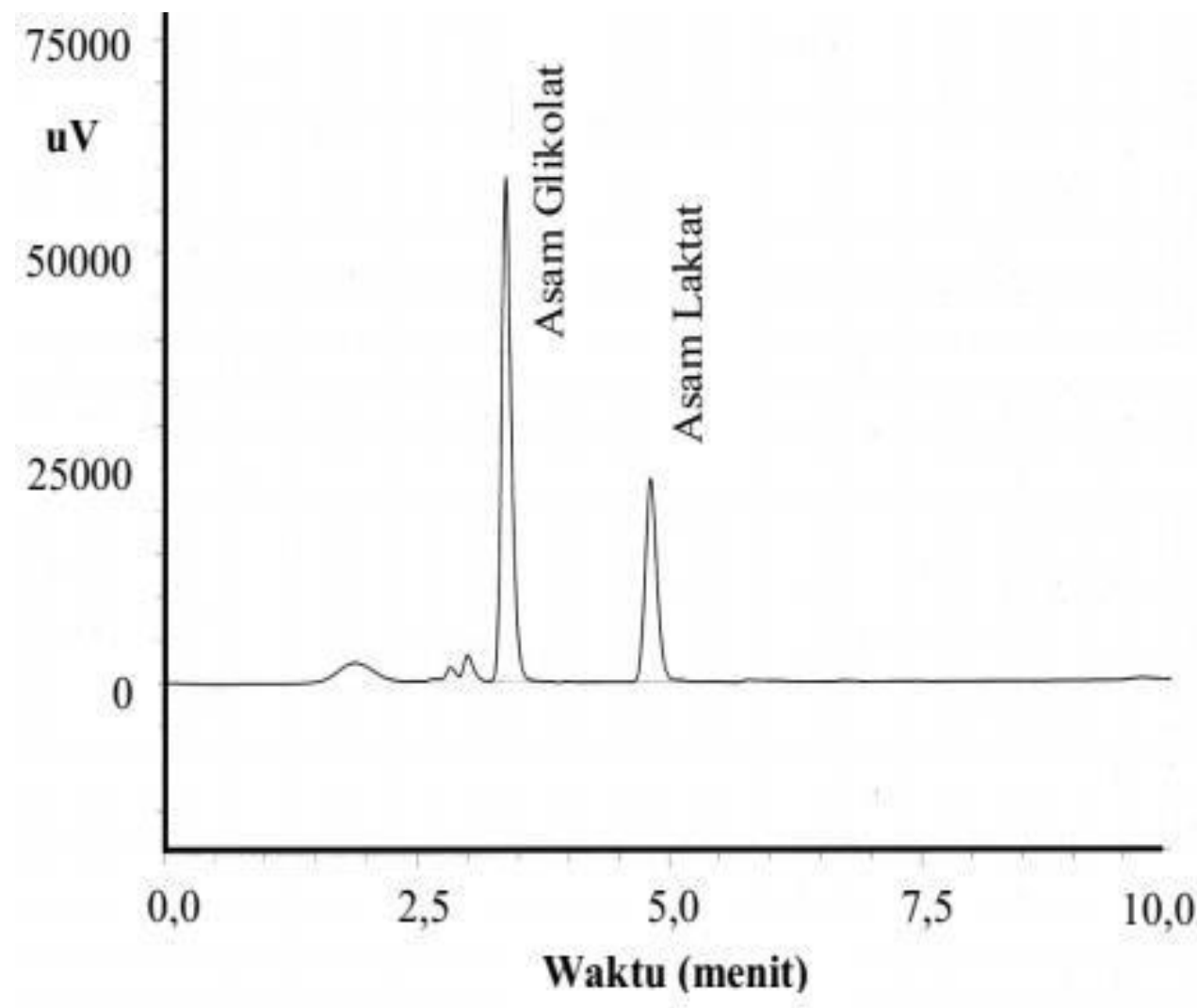

Gambar 2. Kromatogram larutan standar asam glikolat dan asam laktat berkonsentrasi 100 $\mu \mathrm{g} / \mathrm{mL}$ yang dielusi menggunakan pelarut dan fasa gerak asam ortofosfat $0,1 \%, \mathrm{pH} 3,5$ 


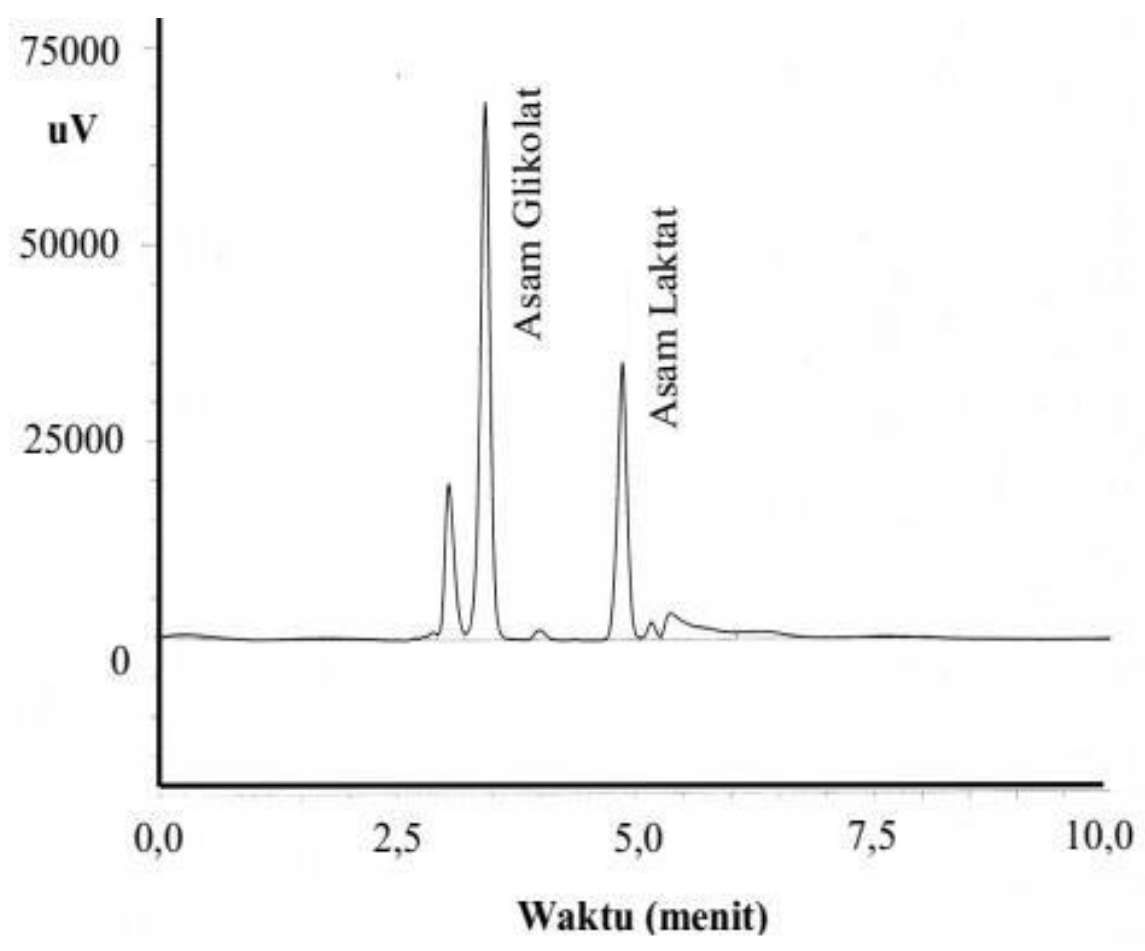

Gambar 3. Kromatogram spiked sample asam glikolat dan asam laktat pada konsentrasi $100 \mu \mathrm{g} / \mathrm{mL}$ menggunakan pelarut dan fasa gerak asam ortofosfat $0,1 \%, \mathrm{pH} 3,5$

Dari hasil optimasi metode secara kromatografi cair kinerja tinggi diperoleh respon asam glikolat dan asam laktat yang paling baik menggunakan pelarut ortofosfat $0,1 \% \mathrm{pH} 3,5$, fasa gerak asam ortofosfat $0,1 \% \mathrm{pH} 3,5$ dengan panjang gelombang detektor $190 \mathrm{~nm}$. Hasil optimasi metode penentuan kadar asam glikolat dan asam laktat dapat dilihat pada Tabel 3.

Tabel 3. Hasil optimasi pemisahan larutan standar asam glikolat dan asam laktat 100 $\mu \mathrm{g} / \mathrm{mL}$

\begin{tabular}{lccccc}
\hline Zat Aktif & $\begin{array}{c}\text { Waktu Retensi } \\
\text { (menit) }\end{array}$ & Area & $\begin{array}{c}\text { Tailing } \\
\text { Factor }\end{array}$ & Resolusi & $\begin{array}{c}\text { Theoretical } \\
\text { Plate }\end{array}$ \\
\hline Asam glikolat & 3,448 & 831829 & 1,099 & 2,251 & 5434,201 \\
Asam laktat & 4,906 & 495203 & 1,072 & 6,313 & 7645,880 \\
\hline
\end{tabular}

\section{Validasi Metode Linearitas}

Uji linearitas dilakukan untuk melihat kemampuan suatu metode memperoleh hasil uji yang secara langsung proporsional dengan konsentrasi analit pada kisaran tertentu. Uji linearitas asam glikolat dan asam laktat dilakukan dengan membuat larutan standar konsentrasi $25 \mu \mathrm{g} / \mathrm{mL}, 50 \mu \mathrm{g} / \mathrm{mL}, 100 \mu \mathrm{g} / \mathrm{mL}, 200 \mu \mathrm{g} / \mathrm{mL}, 400 \mu \mathrm{g} / \mathrm{mL}$. Kurva kalibrasi dibuat dengan cara memplotkan luas area puncak analit terhadap konsentrasi. Hasil uji linearitas dapat dilihat pada Gambar 4 dan 5. 


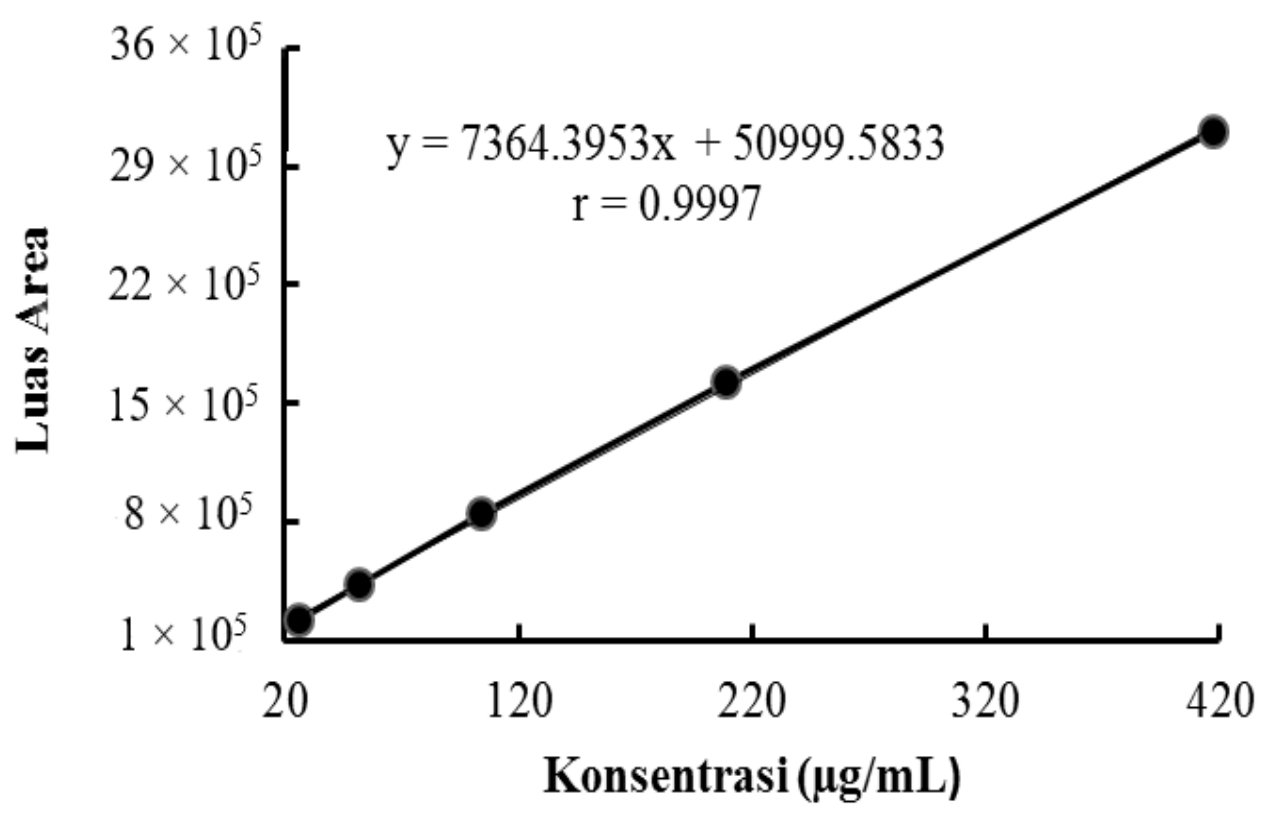

Gambar 4. Kurva kalibrasi larutan standar asam glikolat

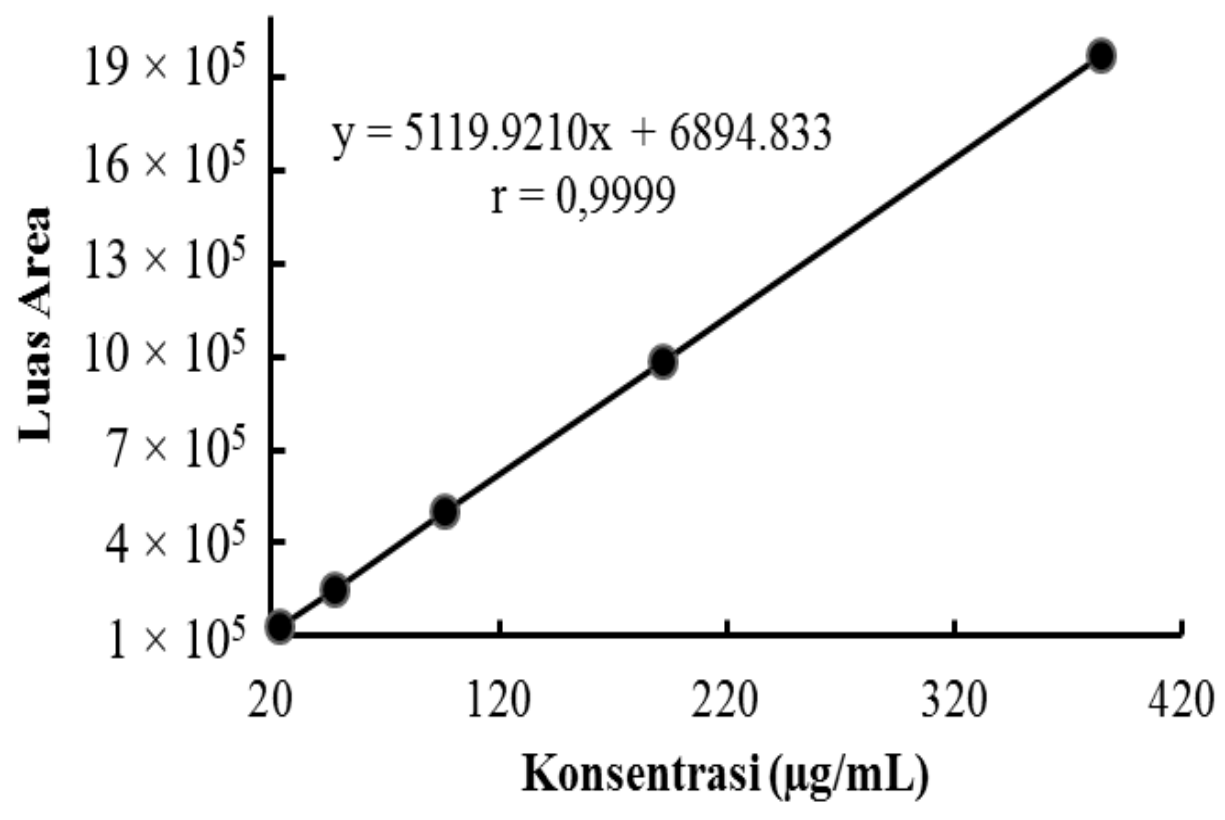

Gambar 5. Kurva kalibrasi larutan standar asam laktat

Gambar 4 dan 5 menunjukkan bahwa terdapat hubungan yang linear antara konsentrasi dan luas area puncak analit. Kriteria keberterimaan menurut ICH dikatakan memenuhi syarat apabila koefisien korelasinya $(r)>0.99$. Harga koefisien korelasi $(r)=+1$ menggambarkan korelasi positif yang sempurna, yaitu semua titik pengukuran terletak pada satu garis lurus dengan kemiringan positif. Nilai koefisien korelasi (r) $\square$ 0,99 yang 
diperoleh dari suatu pengukuran menunjukkan bahwa data pengujian linearitas valid dan terdapat korelasi yang sangat kuat antara konsentrasi dengan luas area (Panggabean et al., 2019).

\section{Presisi}

Presisi merupakan ukuran keterulangan metode analisis dan hasilnya dinyatakan sebagai simpangan baku relatif atau relative standard deviation (RSD). Uji presisi dilakukan menggunakan larutan standar asam glikolat dan asam laktat konsentrasi 100 $\mu \mathrm{g} / \mathrm{mL}$. Larutan standar asam glikolat dan asam laktat diinjeksikan ke dalam alat KCKT sebanyak 10 kali pengulangan dengan waktu dan kondisi analisis yang sama.

Uji presisi asam glikolat menghasilkan $\mathrm{RSD}=1,49 \%$, dan asam laktat $1,72 \%$. Berdasarkan kriteria keberterimaan dari Association of Official Analytical Chemist bahwa batas maksimal nilai RSD untuk analit yang mempunyai konsentrasi $100 \mu \mathrm{g} / \mathrm{mL}$ adalah 5,3\% (AOAC, 1993). Data uji presisi hasil eksperimen ini kurang dari 5,3\% sehingga dapat dinyatakan valid.

\section{Akurasi}

Uji akurasi dilakukan utuk menguji kedekatan antara nilai terukur dengan nilai yang diterima baik nilai konvensi, nilai sebenarnya, atau nilai rujukan. Akurasi diukur sebagai banyaknya analit yang diperoleh kembali (recovery) pada suatu pengukuran dengan melakukan spiking pada suatu sampel. Uji akurasi dilakukan dengan cara membuat larutan spiked sample dengan konsentrasi 50, 100, dan $150 \mu \mathrm{g} / \mathrm{mL}$. Larutan spiked sample dengan tiga konsentrasi yang berbeda diinjeksikan ke dalam alat KCKT. Hasil uji akurasi asam glikolat dan asam laktat dapat dilihat pada Tabel 4.

Tabel 4. Hasil uji akurasi spiked sample asam glikolat dan asam laktat

\begin{tabular}{lcc}
\hline Nama Senyawa & Konsentrasi $(\mu \mathrm{g} / \mathrm{mL})$ & \\
\hline \multirow{3}{*}{ Asam glikolat } & 50 & Recovery \pm SD \\
& 100 & $97,12 \pm 0,69$ \\
& 150 & $100,80 \pm 0,29$ \\
Asam Laktat & 50 & $97,58 \pm 0,39$ \\
& 100 & $96,20 \pm 0,68$ \\
\hline
\end{tabular}

Data akurasi yang tertera pada Tabel 4 memenuhi kriteria keberterimaan Association of Official Analytical Chemist (AOAC). Persyaratan akurasi untuk rasio analit 
dengan konsentrasi $100 \mu \mathrm{g} / \mathrm{mL}$ adalah 90-107\% (AOAC, 1993). Hasil data akurasi eksperimen yang diperoleh masuk dalam rentang yang telah dipersyaratkan sehingga dapat dinyatakan valid.

\section{Batas Deteksi dan Batas Kuantisasi}

Penentuan batas deteksi (LOD) dilakukan untuk mengetahui pada konsentrasi berapa batas terendah dari suatu analit yang bisa dideteksi, meskipun tidak selalu dapat dikuantisasi, sedangkan penentuan batas kuantisasi (LOQ) bertujuan untuk mengetahui konsentrasi terendah analit dalam sampel yang dapat dikuantisasi. Penentuan LOD dan LOQ menurut ICH dapat dilakukan menggunakan pendekatan rasio signal to noise, dimana LOD dihitung dengan rasio signal to noise 3:1 dan LOQ adalah signal to noise 10:1. Noise merupakan gangguan yang berasal dari matriks sedangkan signal adalah respon analit yang ditunjukkan dengan adanya puncak-puncak yang muncul pada kromatogram. Hasil penentuan LOD dan LOQ dapat dilihat pada Tabel 5.

Tabel 5. Hasil penentuan LOD dan LOQ asam glikolat dan asam laktat

\begin{tabular}{lcc}
\hline Nama Senyawa & LOD $(\mu \mathrm{g} / \mathrm{mL})$ & LOQ $(\mu \mathrm{g} / \mathrm{mL})$ \\
\hline Asam glikolat & 0,05 & 0,17 \\
Asam laktat & 1,40 & 4,67 \\
\hline
\end{tabular}

Nilai pengukuran LOD dan LOQ ini merupakan nilai yang menunjukkan batas terendah dimana asam glikolat dan asam laktat dapat terdeteksi dan terkuantisasi oleh alat KCKT. Nilai LOD dan LOQ diperoleh dengan menerapkan metode secara lengkap berdasarkan hasil optimasi.

\section{Kekasaran Metode}

Kekasaran metode (Ruggedness) merupakan parameter untuk mengetahui tingkat keterulangan hasil pengukuran yang diperoleh pada kondisi yang berbeda. Parameter kekasaran dinyatakan sebagai simpangan baku relatif (RSD). Penentuan kekasaran metode bertujuan untuk mengetahui ketahanan fasa gerak dalam waktu dua hari dengan menggunakan KCKT yang berbeda dengan yang digunakan untuk optimasi. Analisis dilakukan menggunakan kolom C-8 pada suhu $30{ }^{\circ} \mathrm{C}$ dan menginjeksikan larutan standar campuran asam glikolat dan asam laktat konsentrasi $100 \mu \mathrm{g} / \mathrm{mL}$ yang sama setelah dua hari penyimpanan. Larutan standar campuran asam glikolat dan asam laktat konsentrasi 100 $\mu \mathrm{g} / \mathrm{mL}$ diinjeksikan sebanyak 6 kali pengulangan. Hasil pengkuran kekasaran metode dapat dilihat pada Tabel 6 . 
Tabel 6. Hasil uji kekasaran asam glikolat dan asam laktat

\begin{tabular}{lcc}
\hline \multirow{2}{*}{ Nama Senyawa } & \multicolumn{2}{c}{ Simpangan Baku Relatif $(\%)$} \\
\cline { 2 - 3 } & Hari 1 & Hari 2 \\
\hline Asam glikolat & 1,43 & 1,67 \\
Asam Laktat & 1,67 & 1,25 \\
\hline
\end{tabular}

Hasil penelitian menunjukkan bahwa fasa gerak, larutan standar, larutan sampel masih dapat digunakan untuk pengukuran dalam jangka waktu maksimal 2 hari. Hal ini di buktikan dengan nilai RSD asam glikolat dan asam laktat yang kurang dari 2,00\%. Pengukuran sampel dalam jangka waktu maksimal 2 hari merupakan antisipasi analisis sampel dalam jumlah yang banyak menggunakan alat KCKT yang dilengkapi dengan autosampler. Hasil penelitian menunjukkan bahwa optimasi dan validasi metode yang telah dilakukan secara keseluruhan memenuhi kriteria keberterimaan dari ICH dan AOAC. Metode yang telah dioptimasi dan divalidasi ini berpotensi untuk diaplikasikan secara spesifik pada penentuan kadar asam glikolat dan asam laktat dalam kosmetik sediaan krim.

\section{KESIMPULAN}

Optimasi dan validasi metode penentuan kadar asam glikolat dan asam laktat dalam krim secara KCKT telah berhasil dilakukan. Hasil validasi metode meliputi linieritas, presisi, akurasi memenuhi persyaratan AOAC dan ICH. Metode yang telah dioptimasi spesifik untuk asam glikolat dan asam laktat dalam krim.

\section{UCAPAN TERIMAKASIH}

Penulis mengucapkan terimakasih kepada Balai Besar POM di Pontianak atas fasilitas laboratorium yang telah digunakan. D. Wulandari juga menyampaikan ucapan terima kasih kepada Badan POM RI atas pembiayaan penelitian melalui beasiswa tugas belajar di Universitas Tanjungpura.

\section{DAFTAR PUSTAKA}

Ahmed, M., Qadir, M.A., Shahzad, S., Waseem, R., Takir, M.S., 2014. Validation of UVHPLC Method for Simultaneous Quantification of Organic Acids in Disinfectants for Haemodialysis Machines. International Journal of Chemistry and Pharmaceutical Sciences 2, 536-540.

Association of Official Analytical Chemist (AOAC), 1993. Peer Verified Methods Program: Manual on Policies and Procedures. AOAC International, Arlington.

Baran, R. and Maibach, H.I., 2010. Cosmetic Dermatology. $4^{\text {th }}$ Edition. CRC Press, USA. 
Burgess, C.M., 2005. Cosmetic Dermatology. Springer, Germany.

Butler, H., 2000. Poucher's Perfumes Cosmetics and Soap. Kluwer Academic Publishers, Great Britain.

Huang, W.S., Lin, C.C., Huang, M.C., and Wen, K.C., 2002. Determination of aHydroxyacids in Cosmetics. Journal of Food and Drug Analysis 10, 95-100. Doi: 10.1016/j.jpba.2005.07.009

International Conference on Harmonization (ICH) Q2B. 1996. Incorporated in Q2 (R1) 2005. Validation of Analytical Procedures: Text and Methodology. Geneva.

Gandjar, I.G. and Rohman, A., 2008. Kimia Farmasi Analisis. Pustaka Pelajar, Yogyakarta

Kishore, G., Karthik, A., Gopal, S.V., Kumar, A.R., Bhat, M., and Udupa, A., 2013. Development RP-HPLC Method for Simultaneous Estimation of Lactic Acid and Glycolic Acid. Scholars Research Library 5, 335-340.

Moldovan, Z., Popa, D.E., David, I.G., Buleandra, M., and Badea, I.A., 2017. A Derivative Spectrometric Method for Hydroquinone Determination in the Presence of Kojic Acid, Glycolic Acid, and Ascorbic Acid. Journal of Spectroscopy 2017, 1-9. Doi: 10.1155/2017/6929520.

Molever, K., 2002. Simultaneous Determination of Alpha and Beta Hydroxy Acids in Personal Care Products by Capillary Gas Chromatography. Journal of Cosmetic Science 53, 121-126.

Mubarak, M.A.S.L., Lamari, F.N., and Kontoyannis, C., 2013. Simultaneous Determination of Allantoin and Glycolic Acid in Snail Mucus and Cosmetic Creams with High Performance Liquid Chromatography and Ultraviolet Detection. Journal of Chromatography A 1322, 49-53. Doi: 10.1016/j.chroma.2013.10.086.

Panggabean, A.S., Widyastuti, T., and Hindryawati, N., 2019. Validasi Metode Penentuan Benzena, Toluena dan Xilena pada Sampel Udara dan Tanah Menggunakan Kromatografi Gas. ALCHEMY Jurnal Penelitian Kimia 15(1), 177-189. Doi: 10.20961/alchemy.15.1.25522.177-189.

Peraturan Kepala Badan Pengawas Obat dan Makanan Republik Indonesia No.18, 2015. Persyaratan Teknis Bahan Kosmetika. BPOM., Jakarta.

Raeni, S.F., Haresmawati, U., Mulyasuryani, A., and Sabarudin, A., 2018. Evaluasi Pemisahan Alkilbenzena Menggunakan Kolom Monolith Berbasis Polimer Organik secara Kromatografi Kinerja Tinggi. ALCHEMY Jurnal Penelitian Kimia 14(1), 3750. Doi: 10.20961/alchemy.14.1.11266.37-50.

Snyder, L.R., Kirkland, J.J., and Glajch, J.L., 1997. Practical HPLC Method Development. John Wiley \& Sons, Canada.

Zamanova, M.K., Glotova, V.N., Izhenbina, T.N., Krutas, D.S., and Novikov, V.T., 2014. Simultaneous HPLC-UV Determination of Lactic Acid, Glycolic Acid, Glycolide, Lactide, and Ethyl Acetate in Monomers for Producing Biodegradable Polymers. Procedia Chemistry 10, 244-251. Doi: 10.1016/j.proche.2014.10.041. 